
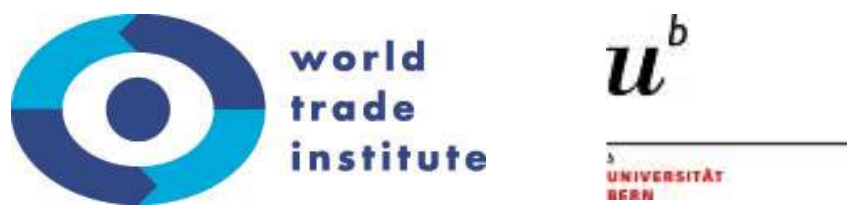

\title{
Facilitating the Protection of Geographical Indications in ASEAN
}

\author{
Le Thi Thu Ha \\ Foreign Trade University (FTU), Vietnam \\ halt@ftu.edu.vn
}

Even if many of the ASEAN Member States (AMS) had geographical indication protection prior to the TRIPS Agreement and before joining the WTO through unfair competition, consumer protection, and food standards or even appellation of origin, adhesion to the WTO was for many ASEAN countries the occasion to adopt new legal protection schemes for geographical indications, following pressure from the more developed nations in WTO's accession. ASEAN countries are also involved in numerous regional and bilateral free trade agreements (RTAs and FTAs), and have implemented a wide range of initiatives for the protection of geographical indications. ASEAN, thus, became one of the most active geographical indication protected areas in the world. This research provides an overview these issues. Chapter I begins with a brief background to the protection for geographical indications in ASEAN countries and a comparative analysis of ASEAN countries domestic laws. Chapter II describes possibilities for adopting a more interoperable approach to protections for geographical indicators in ASEAN. Finally, Chapter III focuses on the possible ways to facilitate the registration and protection of geographical indications in the ASEAN region. 


\section{FINAL REPORT \\ FACILITATING THE PROTECTION OF GEOGRAPHICAL INDICATIONS IN ASEAN $^{1}$}

Researcher

Collaborator
: Ass., Prof Dr Le Thi Thu Ha

Foreign Trade University

: Dr Delphine Marie-Vivien

UMR Innovation, CIRAD

${ }^{1}$ This Research was supported by the Swiss State Secretariat for Economic Affairs under the SECO/WTI Academic Cooperation Project, based at the World Trade Institute of the University of Bern, Switzerland. 


\section{TABLE OF CONTENTS}

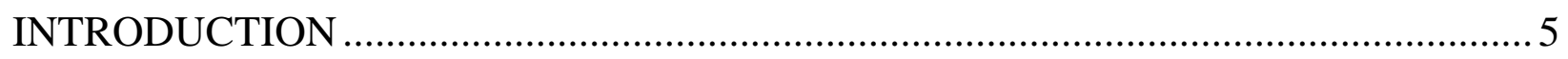

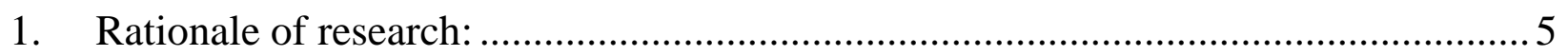

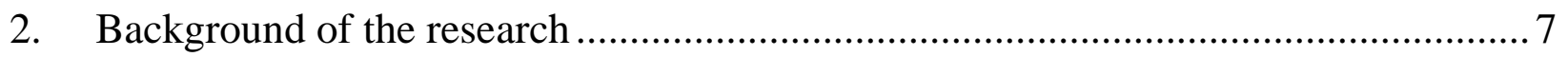

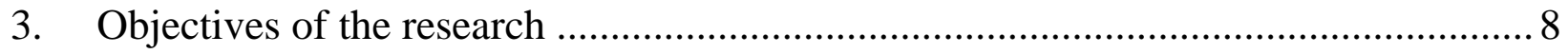

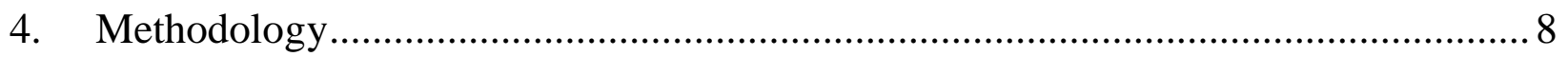

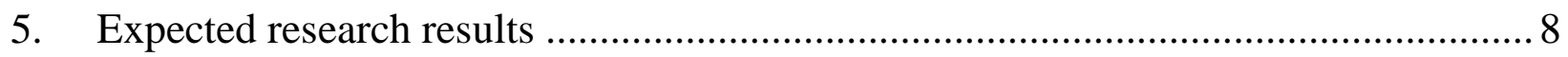

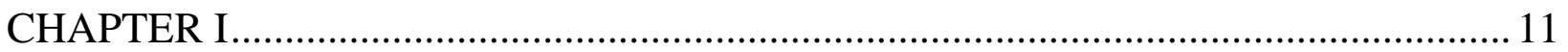

OVERVIEW OF GEOGRAPHICAL INDICATION PROTECTION ............................ 11

I. International framework of geographical indication protection ................................. 11

1. The protection of GIs before the TRIPS Agreement ............................................... 11

2. The protection of GIs under the TRIPS Agreement ............................................... 14

II. Regional framework of geographical indication protection in ASEAN ................... 15

1. The history of GI protection in ASEAN ............................................................. 15

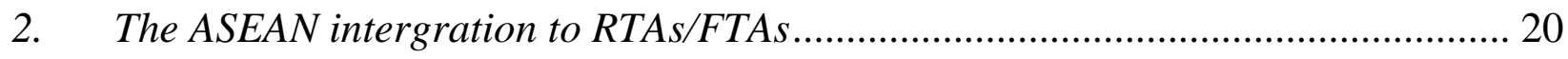

III. The national legal framework on geographical indication protection ..................... 21

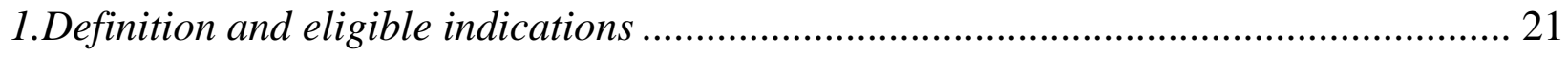

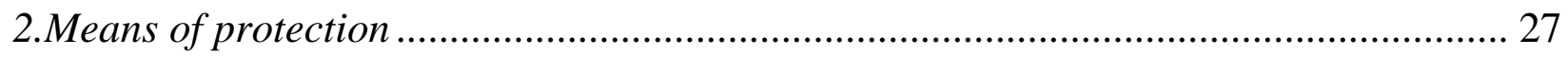

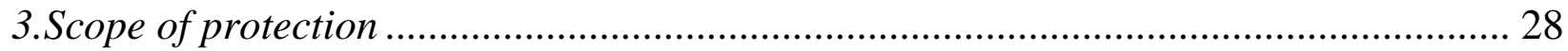

CHAPTER II: EXISTING PROTECTION FRAMEWORK FOR THE PROTECTION OF GEOGRAPHICAL INDICATIONS AT THE INTERNATIONAL AND REGIONAL

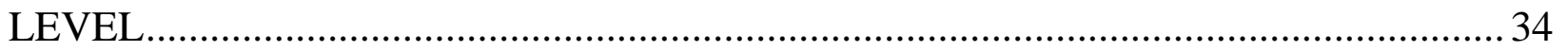

I. International notification and registration system of Geographical Indications ......... 34

1. The freeze in the international negotiations TRIPS ................................................ 34

2. The newborn Geneva Act of the Lisbon Agreement ............................................... 38 
II. Existing regional registration system of Geographical Indications

1. EU System

2. West Africa ....................................................................................... 43

III. Challenges for geographical indication protection in ASEAN countries .............. 44

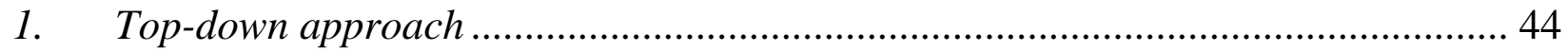

2. Economic value from geographical indications .............................................. 45

3. The costs of establishing and administering a geographical indication protection regime

4. Technical assistance and capacity building .................................................... 48

CHAPTER III: FACILITATING THE PROTECTION SYSTEM OF GEOGRAPHICAL INDICATIONS IN ASEAN

I. Harmonization of national legal framework of ASEAN countries pushed by FTAs/RTAs

II. ASEAN as a unique partner.

III. Regional geographical indication website and Mandatory Database with all geographical indication registered in ASEAN for each country....

IV. Legal effects to the Mandatory Database with all geographical indications registered in ASEAN 


\section{INTRODUCTION}

\section{Rationale of research:}

The Association of Southeast Asian Nations (ASEAN) was established in 1967 and became the ASEAN Community which includes the ASEAN Economic Community (AEC) - a single market and production base in $2015 .^{2}$ The establishment of the AEC offers opportunities in the form of a huge market of US\$2.6 trillion and over 622 million people, ${ }^{3}$ which will allow the free flow of goods, services, investments, skilled labour, and the free movement of capital across the region. ${ }^{4}$ Intellectual property rights (IPRs) are one issue in establishing a single market as it was in the European Union (EU). The first ASEAN Framework Agreement on Intellectual Property Cooperation in 1995 recognizes the important role of IPRs in the region, including geographical indication protection. ${ }^{5}$

Geographical indications is defined in the Agreement on Trade-Related Aspects of Intellectual Property Rights (TRIPS) and become one of the most contentious intellectual property issues in the WTO and multiple treaties. ${ }^{6}$ Geographical indications are "...indications which identify a good as originating in the territory of a Member, or a region or locality in that territory, where a given quality, reputation or other characteristic of the good is essentially attributable to its geographical

\footnotetext{
${ }^{2}$ Ten ASEAN countries presently make up ASEAN: Brunei, Cambodia, Indonesia, Lao, Malaysia, Myanmar, the Philippines, Singapore, Thailand and Vietnam. Timor-Leste is an observer country.

${ }^{3}$ See ASEAN website: http://www.asean.org/asean-economic-community/, last accessed on 15/12/2016

4 See the $24^{\text {th }}$ ASEAN Summit (2014), Nay Pyi Taw Declaration, available at http://www.asean.org/storage/images/documents/24thASEANSummit/Nay\%20Pyi\%20Taw\%20Declaration.pdf, last accessed on 15/12/2016

${ }^{5}$ The ASEAN Framework Agreement on Intellectual Property Cooperation is signed on 15 December 1995 in Bangkok by Thailand, Brunei, Indonesia, Malaysia, Philippines, Singapore and Viet Nam, available at: https://www.aseanip.org/Portals/0/PDF/ASEANFrameworkAgreementonIntellectualPropertyCooperation.pdf, last accessed on 15/12/2016

${ }^{6}$ WIPO (2004), Geographical Indications: historical backgrounds, nature of rights, existing system for protection and obtaining protection in other countries, WIPO document SCT/8/4, available at: http://wipo.int/edocs/mdocs/sct/en/sct_8/sct_8_4.pdf, last accessed on 15/12/2016
} 
origin. "7 This concept is a coined bridge between the two old notions of Indication of Source and Appellation of Origin. A convergence of new concept in TRIPS agreement cannot stop the divergence between Party advocating stronger multilateral protection for geographical indications and Party favouring a less ambitious outcome, led by the European Union (EU) and United States (US). ${ }^{8}$

Even if many of the ASEAN Member States (AMS) had geographical indication protection prior to the TRIPS Agreement and before joining the WTO through unfair competition, consumer protection, and food standards or even appellation of origin, adhesion to the WTO was for many ASEAN countries the occasion to adopt new legal protection schemes for geographical indications, following pressure from the more developed nations in WTO's accession. ASEAN countries are also involved in numerous regional and bilateral free trade agreements (RTAs and FTAs), and have implemented a wide range of initiatives for the protection of geographical indications. ASEAN, thus, became one of the most active geographical indication protected areas in the world.

Yet, beyond the protection of geographical indications at domestic level in ASEAN Member States (AMS), the question is whether there is any regional geographical indications protection at ASEAN level and if not whether there should be any. Indeed, the hypothesis is that creating a single market in ASEAN should be associated with the availability of legal tools, including ASEAN level intellectual property protection supporting the single market. In the field of intellectual property, it means various options from harmonization of domestic legal framework, facilitation of protection of IPRs within the ASEAN market itself, or creation of unique IPR are valid and enforced in all ASEAN countries.

\footnotetext{
${ }^{7}$ See TRIPs Agreement, art 22.1.

${ }^{8}$ Le Thi Thu Ha, The new evolution of protection of geographical indications, VNU Journal of Science: Policy and Management Studies, Vol. 32, No. 1 (2016) 68-78
} 
To look at such an issue, Chapter I begins with a brief background to the protection for geographical indications in AMS and a comparative analysis of AMS domestic laws. In order to give some options to facilitate the protection of geographical indications within ASEAN, Chapter II describes the existing facilitation framework for the protection of geographical indications at the international level and at the regional level in some areas in the world, namely the EU and the West African countries. Finally, Chapter III is going to focus on the possible ways to facilitate the registration and protection of geographical indications in the ASEAN region.

\section{Background of the research}

Though geographical indications are considered as the Sleeping Beauty of the intellectual property world, ${ }^{9}$ there has been a widespread literature on the international protection of GIs.

From general approach, there exists significant research and analysis on various aspects of GI protection including international framework for GI protection; socioeconomics of GI protection; the scope of obligations under the TRIPS Agreement including the negotiating history of the provisions; the development implications of GI protection; the available legal means of GI protection in various jurisdictions around the world; the relationship between GIs and trademarks.

For ASEAN, however, there are shortcomings in the existing literature. The first study which covers ASEAN is by N.S. Gopalakrishnan, Prabha S. Nair \& Aravind K. Babu (2007) "Exploring the Relationship between Geographical Indications and Traditional Knowledge" which contains detailed information about the legal protection of GIs in various ASIA countries including AMS. The more significant study is by Malobika Banerji, "Geographical Indication: which way should ASEAN

\footnotetext{
${ }^{9}$ Marcus Höpperger, in Elizabeth March, Geographical Indications: From Darjeeling to Doha, WIPO Magazine; July 2007, online at: http://www.wipo.int/wipo_magazine/en/2007/04/article_0003.html, last accessed on 12/12/2016 
go", reviews the negotiation mandated by TRIPS and the deadlock in international level. The author raised the issue whether or not it is possible for ASEAN countries, to take a position with either camp.

It should be noted, however, that a conclusive picture on the exact state of GI protection in ASEAN countries. While there is any progress on negotiations for a multilateral register for wines and no consensus is possible on the extension of subject matter eligible for higher protection, this research focus on the resolution to facilitate GIs protection for ASEAN countries.

\section{Objectives of the research}

This research provides an overview these issues. Chapter I begins with a brief background to the protection for geographical indications in ASEAN countries and a comparative analysis of ASEAN countries domestic laws. Chapter II describes possibilities for adopting a more interoperable approach to protections for geographical indicators in ASEAN. Finally, Chapter III focuses on the possible ways to facilitate the registration and protection of geographical indications in the ASEAN region.

\section{Methodology}

This research will be conducted by using the method of comparative law and empirical field research in ASEAN countries.

\section{Expected research results}

A key challenge for ASEAN countries participating in international and regional integration is adopting an interoperable approach for the positions they take. This research is to gather and analyse information and evidence on:

- The evolution of legal framework of GI protection in the world;

- The GI legislation adaptation of ASEAN countries to international framework; 
- Regional approaches to GI protection in the world and challenges for ASEAN

- Possibilities for greater inter-operability in the ASEAN context. 


\section{ACKNOLEDGEMENT}

I express my sincere gratitude to the Foreign Trade University, Vietnam and Swiss State Secretariat for Economic Affairs under the SECO/WTI Academic Cooperation Project, based at the World Trade Institute of the University of Bern, Switzerland for their support during my study.

I am especially thankful to my research collaborator Dr Delphine Marie-Vivien, Researcher, UMR Innovation, CIRAD, France. She really becomes my companion in the field of geographical indication.

I would like to express my sincere thanks to Associate Professor Dr Sufian Jusoh (WTI) for his valuable comments on the first draft report and then his contribution on the completion of this research. 


\section{CHAPTER I}

\section{OVERVIEW OF GEOGRAPHICAL INDICATION PROTECTION}

Geographical indication protection has a long tradition in many of the ASEAN countries through unfair competition, consumer protection, and food standards or even appellation of origin. The adherence to the WTO, then RTAs and FTAs for many ASEAN countries provides an opportunity to adopt new legal protection schemes for geographical indications. A convergence of new concept in legal framework, however, cannot stop the divergence in geographical indication operation. This section provides an overview of geographical indications in the world (I), the history and integration of geographical indication protection in ASEAN (II), and a comparison of the domestic laws' compliance to TRIPS Agreement.

\section{International framework of geographical indication protection}

The increasing interest and use of origin-related signs has made GIs a subject of different national concepts such as appellation of origin, indication of source and designation of origin in $19^{\text {th }}$ Century. The international protection for GIs, marked by TRIPS Agreement can be divided into 2 period: before and after the adoption of TRIPS Agreement.

\section{The protection of GIs before the TRIPS Agreement}

The Paris Convention for the Protection of Industrial Property of 1883 (hereinafter "the Paris Convention"), for the first time, recognized appellations of geographic origin or indications of source as protected subject matter of industrial property. Article 1(2) provides:

"The protection of industrial property has as its object patents, utility models, industrial designs, trademarks, service marks, trade names, 
indications of source or appellations of origin, and the repression of unfair competition." 10

However, this first international Convention undefined the meaning, scope and coverage of the concepts, but provide enough flexibility to the Member States to structure the domestic laws to suit their local requirements.

Article 10.1 prohibits the direct and indirect use of false indications of the source of goods or identity of the producer, manufacturer or merchant. ${ }^{11}$ Thus, the terms 'appellations of geographic origin' or 'indications of source' became territorial links only and do not emphasize the particular characteristics, quality or reputation of the goods. Further, Article 10bis of the Convention defines an act of unfair competition as "any act of competition contrary to honest practices in industrial and commercial matters". ${ }^{12}$

Thus, the Paris Convention is silent about the reputation, quality of the product and consumer deception or confusion concerning the geographical origin. There are no special remedies against infringement of this provision.

The Madrid Agreement for the Repression of False or Deceptive Indications of Source on Goods of 1891 (hereinafter the Madrid Agreement) was the first international agreement to provide specific rules for the repression of false and deceptive indications of source. The Agreement do not add much to the protection already given by the Paris Convention but required the indication being protected under domestic law. It protects all the direct and indirect indications of source of the Contracting Parties against false or misleading use and this protection is extended to any use in commercial transactions.

"All goods bearing a false or deceptive indication by which one of the

\footnotetext{
${ }^{10}$ The Paris Convention, Article 1.2.

${ }^{11}$ Ibid., Article 10.1

${ }^{12}$ Ibid., Article 10bis.2
} 
countries to which this Agreement applies, or a place situated therein, is directly or indirectly indicated as being the country or place of origin shall be seized on importation into any of the said countries."

The Madrid Agreement do not protect generic appellations and let the court of each country to decide whether a GI constitutes an indication of source protected by the Agreement or is a generic name. ${ }^{14}$

The Lisbon Agreement for the Protection of Appellations of Origin and their Registration, 1958 (hereinafter the Lisbon Agreement) clearly defined the concept of appellations of origin as the

"Geographical name of a country, region, or locality, which serves to designate a product originating therein, the quality and characteristics of which are exclusively or essentially due to the geographical environment, including natural and human factors $", 15$

It is mandatory that geographical names should identify the product and any other name indicating the product cannot be protected as an appellation of origin under the Lisbon Agreement. This makes it clear that non-geographical names are excluded from the scope of protection. There is also a clear link between the products and their place of origin through quality and characteristics of the products attributable to the various factors of the place of origin.

The free riding on the reputation of indications is regulated in the Lisbon Agreement by ensuring protection against any usurpation or imitation even if the true origin of the product is indicated or the appellation is used in translated form or accompanied by terms such as kind, type, or imitation. ${ }^{16}$ It is clear that Lisbon stands as an

\footnotetext{
${ }^{13}$ The Madrid Agreement of 1891, Art 1.1

${ }^{14}$ Ibid., Article 4

15 The Lisbon Agreement of 1958, art 1

${ }^{16}$ Ibid., Article 3
} 
effective mechanism in protecting appellations of origins.

Both first international conventions, however, have very limited membership. The Madrid Agreement on Indications of Source has only 35 members while the Lisbon Agreement has 26 members. Among the main international treaties related to the protection of geographical indications before TRIPS Agreement, ASEAN Member States are only signatories of the Paris Convention. ${ }^{17}$ The restricted participation of ASEAN Member States in these international treaties also means that these nations were limitedly integrated in the international system for the protection of geographical indications until the WTO's establishment.

\section{The protection of GIs under the TRIPS Agreement}

The TRIPS Agreement is one of the most significant multilateral agreement for the international protection of GIs. ${ }^{18}$ There are two level of GI protection.

First, a minimum protection for all products in the WTO Members against

"the use of any means in the designation or presentation of a good that indicates or suggests that the good in question originates in a geographical area other than the true place of origin in a manner which misleads the public as to the geographical origin of the good",19

The Article 22 protection is therefore to provide an ground to prevent misleading indications and acts of unfair competition under Article 10bis of the Paris Convention.

Article 23 of the TRIPS Agreement provides the additional protection for wines and spirits by requiring WTO Members to provide legal means for

\footnotetext{
${ }^{17}$ All ASEAN countries are members of Paris Convention except Myanmar. The author considers the participation in Paris Convention of ASEAN members is due to the interest in other Intellectual Property subject matters such as trademark or patent, not geographical indication.

${ }^{18}$ Gervais, The TRIPS Agreement: drafting history and analysis, Sweet and Maxwell, London, 2003

${ }^{19}$ The TRIPS Agreement, Art 22.1
} 
"interested parties to prevent use of a geographical indication identifying wines for wines not originating in the place indicated by the geographical indication in question or identifying spirits for spirits not originating in the place indicated by the geographical indication in question, even where the true origin of goods is indicated or the geographical indication is used in translation or accompanied by expressions such as "kind”, “type”, "style”, “imitation” or the like.",20

Article 23 also turns on the problem of notification and registration system by providing a mandate for the Council for TRIPS to undertake negotiations on the establishment of a multilateral system of notification and registration of GIs for wines. These issues have been addressed to the Doha Round Agenda as well as new proposals by a number of WTO Members for the extension of the protection provided for wines and spirits under Article 23 to all products.

\section{Regional framework of geographical indication protection in ASEAN}

At the national level, protection of GIs has developed differently in different countries. This section provides a brief background to the participation of ASEAN in the international GI protection systems and the integration of ASEAN in RTAs/FTAs.

\section{The history of GI protection in ASEAN}

Geographical indication protection has a long tradition in many of the ASEAN countries through unfair competition, consumer protection, and food standards or even appellation of origin. Among three main international treaties related to the protection of geographical indications before TRIPS Agreement, AMS are only signatories of the Paris Convention. ${ }^{21}$ The restricted participation of AMS in these

\footnotetext{
${ }^{20}$ Ibid., Article 23

${ }^{21}$ All ASEAN countries are members of Paris Convention except Myanmar. The author considers the participation in Paris Convention of ASEAN members is due to the interest in other Intellectual Property subject matters such as trademark or patent, not geographical indication.
} 
international treaties also means that these nations were limitedly integrated in the international system for the protection of geographical indications until the WTO's establishment. The legal protection as envisaged under the TRIPS Agreement seems never to have existed in these countries. ${ }^{22}$

Being member of the $\mathrm{WTO},{ }^{23}$ AMS undertook extensive reforms and engaged themselves in establishing a comprehensive and modern intellectual property legal . Up to date, AMS are currently reviewing their national legislation to go beyond basic TRIPS compliance. Support in this process was provided by WIPO and many international and regional organizations in which EU plays a very active role. As a result, seven out of ten ASEAN countries have sui generis system regulating geographical indications protection. (See Table 1). The remaining three countries (Philippine, Brunei and Myanmar) protect geographical indications through certifications or collective trademarks under national trademark laws. The Philippines recently drafted Rules and Regulation on geographical indications $(2014)^{24}$, whilst Myanmar allows protection through the Trademark Law of Myanmar ${ }^{25}$ which was approved in September 2014. On the other hand Brunei plans to develop a specific law on geographical indication. Although the least developed countries are given an extended transition period to protect intellectual property rights under TRIPS Agreement until July 2021, ${ }^{26}$ the setting up of geographical indication legal framework shows the intention of three LDCs in ASEAN

\footnotetext{
${ }^{22}$ Gopalakrishnan, N.S. et al (2007) Exploring the Relationship between GIs and TK: An Analysis of the Legal Tools for the Protection of GIs in Asia, ICTSD Programme on Intellectual Property Rights and Sustainable Development, International Centre for Trade and Sustainable Development, Geneva, Switzerland.

${ }^{23}$ All ASEAN countries are now member of WTO since Lao's accession in February 2013

24 The drafted proposed rules and Regulation on geographical indications of the Philippines, available at: http://www.ipophil.gov.ph/images/WhatsNew/Draft-Rules\&Regulationsongeographical indications.docx, last accessed on $15 / 12 / 2016$

${ }^{25}$ In this draft, chapter 7 rules for geographical indications

${ }^{26}$ List of Least-developed countries designated by the United Nations and recognized by WTO, available at: https://www.wto.org/english/thewto_e/whatis_e/tif_e/org7_e.htm See IP/C/64, available at: https://www.wto.org/english/tratop_e/trips_e/ldc_e.htm, last accessed on 15/12/2016
} 
(Myanmar, Cambodia and Laos) to provide geographical indication protection system. Besides engaging in legislative amendments, ASEAN countries are also involved in upgrading intellectual property office for geographical indication registration and the promotion of using geographical indication among stakeholders and potential geographical indication beneficiaries as tools for economic development. There have been nearly 200 products that are currently being registered or are in the process of registration as geographical indication (see Table 2). Some countries allow and accept the registration and recognition for both national and foreign geographical indications (Thailand ${ }^{27}$, Vietnam $^{28}$, Malaysia ${ }^{29}$, Cambodia, Lao, Myanmar ${ }^{30}$ and Indonesia ${ }^{31}$ ). The number of foreign geographical indication registered in ASEAN is increasing through FTAs signed with the EU. However, the protection of geographical indication originating from ASEAN in third countries is very limited mainly due to the difference in the requirement of the GI sui generis system. Cross registration of GIs within ASEAN countries is on the start. $^{32}$

\section{Table 1: Legal regime of ASEAN}

\footnotetext{
2711 geographical indications protected in Thailand include Prosciutto di Parma Ham (Italy) Pisco Peru (Peru), Champagne (France), Brunello di Montalcino (Italy), Cognac (France), Scotch Whisky (UK), Napa Valley (USA), Tequila (Mexico), Barolo (Italy), Barbaresco (Italy)

${ }^{28}$ Foreign geographical indications protected in Vietnam include Cognac (France), Pisco (Peru), Scotch Whisky (UK), Isan Indigenous Silk Yarn (Thailand)

${ }^{29}$ Foreign geographical indications protected in Malaysia include Cognac (France), Tequila (Mexico), Barolo (Italy), Prosciutto di Parma Ham (Italy), Pisco Peru (Peru), Champagne (France), Scotch Whisky (UK)

${ }^{30}$ Champagne is registered in Myanmar

${ }^{31}$ Champagne is registered in Indonesia

${ }^{32}$ There are no official statistics defined the geographical indications originating from ASEAN in third countries. The author compiled and updated from different IP portal of ASEAN members and reports of regional geographical indications projects (ECAP/FAO/AFD).

- In Thailand, geographical indications Khao Hom Mali Thung Kula Rong is registered in EU in 2013, Isan Indigenous Silk Yarn is registered in Vietnam in 2014, and 3 other applications of Kafae Doi Chaang (Coffee), Kafae Doi Tung (Coffee) and Khao Sungyod Muang Phattalung (Rice) are pending at the EU.

- Cambodia has only one geographical indications application of Kampot Pepper pending at the EU.

- Vietnam also got one geographical indications Phu Quoc registered in EU but 38 other Vietnamese geographical indications are protected in this market through the Vietnam-EU FTAs.
} 


\begin{tabular}{|l|c|c|c|}
\hline \multicolumn{1}{|c|}{ Country } & Specific GI protection & $\begin{array}{c}\text { Trademark } \\
\text { regime }\end{array}$ & Unfair Competition \\
\hline Thailand & $*$ & & $*$ \\
\hline Vietnam & $*$ & & $*$ \\
\hline Laos & $*$ & & $*$ \\
\hline Cambodia & $*$ & & $*$ \\
\hline Indonesia & $*$ & $*$ & $*$ \\
\hline Malaysia & & $*$ & $*$ \\
\hline Myanmar & $*$ & $*$ & $*$ \\
\hline Singapore & & & $*$ \\
\hline Brunei & & & $*$ \\
\hline Philippines & & & $*$ \\
\hline
\end{tabular}

Source: WTO 
Table 2: Number of registered geographical indications in ASEAN

\begin{tabular}{|c|c|c|c|c|c|}
\hline \multirow{2}{*}{ Country } & \multirow{2}{*}{$\begin{array}{l}\text { GIs in the } \\
\text { country of } \\
\text { origin }\end{array}$} & \multirow{2}{*}{$\begin{array}{l}\text { GIs originating } \\
\text { from ASEAN in } \\
\text { third countries }\end{array}$} & \multicolumn{2}{|c|}{$\begin{array}{l}\text { Foreign GIs registered with } \\
\text { regular procedure }\end{array}$} & \multirow{2}{*}{$\begin{array}{c}\text { Foreign GIs } \\
\text { protected } \\
\text { with FTA }\end{array}$} \\
\hline & & & $\begin{array}{l}\text { From outside } \\
\text { ASEAN }\end{array}$ & $\begin{array}{c}\text { From } \\
\text { ASEAN }\end{array}$ & \\
\hline Thailand & 55 & $\begin{array}{c}2 \text { registered and } \\
3 \text { pending at } E U \\
1 \text { registered in } \\
\text { Vietnam }\end{array}$ & 11 & 0 & \\
\hline Vietnam & 48 & $\begin{array}{c}39 \text { protected in } \\
\text { EU and } 2 \\
\text { pending in } \\
\text { Thailand } \\
\end{array}$ & 3 & 1 & $169 \mathrm{EU}$ \\
\hline Laos & - & & - & - & \\
\hline Cambodia & 2 & 3 pending in $\mathrm{EU}$ & - & - & \\
\hline Indonesia & 23 & & - & - & \\
\hline Malaysia & 48 & & 7 & - & \\
\hline Myanmar & - & & 1 & - & \\
\hline Singapore & - & & - & - & \\
\hline Brunei & - & & - & - & \\
\hline Philippines & - & - & - & - & \\
\hline
\end{tabular}




\section{The ASEAN integration to RTAs/FTAs}

The ASEAN individual member countries are involved in a network of RTAs/FTAs in the recent past ${ }^{33}$ ASEAN, as a bloc entity, also negotiates and enters into RTAs and FTAs with Australia and New Zealand, China, India, Japan, and South Korea. None of the FTAs deal with the geographical indications.

The only FTA that ASEAN negotiated, and now being put on hold, deals with geographical indications is the ASEAN-EU FTA. Regarding the negotiations with the EU, the IPRs chapter in the EU FTA template reflects the EU's advocacy of a specialized system for the registration of geographical indication and of enhanced and extended protection for geographical indications. ${ }^{34}$ The negotiations for the now abandoned EU_ASEAN FTA were launched in July 2007. Due to the lack of progress, in March 2009, both parties took a pause in the regional negotiations. In December 2009, EU Member States agreed that the EU Commission would pursue bilateral FTA negotiations with ASEAN Member States Negotiations with Singapore and Malaysia were launched in 2010, with Vietnam in June 2012, with Thailand in March 2013, with the Philippines in December 2015 and with Indonesia in July 2016. Negotiations of an investment protection agreement are also under way with Myanmar (Burma).

The European Commission finalised negotiations of FTA with Singapore in October 2014 and with Vietnam in December 2015. ${ }^{35}$ The two FTAs EU-Singapore and EUVietnam have some similarities, with the obligation to provide for a sui generis system comprising a register, an administrative process to evaluate the existence of a

\footnotetext{
${ }^{33}$ Individual member countries of ASEAN are involved in a total of 156 FTAs in varying stages of development. The authors compiled from the ADB' statistics, available at: https://aric.adb.org/fta-country, last accessed on 12/12/2016

34 Chuthaporn Ngokkuen and Ulrike Grote (2012), Challenges and opportunities for protectiong geographical indications in Thailand, Asia-Pacific Development Journal, Vol. 19, No. 2, December 2012

${ }^{35}$ See more at: http://ec.europa.eu/trade/policy/countries-and-regions/regions/asean/, last accessed on 12/12/2016
} 
link with the origin, an objection procedure and legal means that permit the rectification and cancellation of entries on the domestic register, the right of use of the geographical indication to any complying producer without further requirements. ${ }^{36}$ Yet these principles of sui generis law are already implemented in most of ASEAN countries, with thus little impact of the FTAs on the homogenization of the legislation within ASEAN.

At regional level, the ASEAN has built an Intellectual Property Action Plan (20112015) identifying five strategic goals ${ }^{37}$ that should contribute to the collective transformation of ASEAN into a competitive region with the use of intellectual property.

\section{The national legal framework on geographical indication protection}

As with other IPRs, there is no common legal framework for the protection of geographical indications at the level of ASEAN, so the legal framework in each ASEAN country is examined as the compliance to TRIPS Agreement. At this stage it seems to be necessary to assess what are the differences of the domestic laws for the three major points being: definition and eligible indications (1); mean of protection (2); and scope of protection including the conflict between geographical indication and trademark (3).

\section{Definition and eligible indications}

The definition of geographical indication in TRIPS which differs from previous relating concepts as Appellations of Origin ${ }^{38}$ and Indications of Source ${ }^{39}$, becomes the model for ASEAN countries:

\footnotetext{
${ }^{36}$ See http://trade.ec.europa.eu/doclib/docs/2006/december/tradoc 118238.pdf, last accessed on 12/12/2016

37 For the full text of the ASEAN IPR Action Plan 2011-2015, See more at https://www.aseanip.org/Portals/0/PDF/ASEAN\%20IPR\%20Action\%20Plan\%202011-2015.pdf

38 The term "appellation of origin" is quoted in the Madrid Agreement 1891, and then defined in the Lisbon Arrangement 1958. According to the latter, an 'appellation of origin' is the geographical name of a country, a region or a territory and is used to indicate a product that originates from it and the quality and characteristics of which are exclusively or mainly due to the geographical environment, including the natural and human factors.
} 
...Geographical indications are [...] indications which identify a good as originating in the territory of a Member, or a region or locality in that territory, where a given quality, reputation or other characteristic of the good is essentially attributable to its geographical origin. ${ }^{40}$

This concept is flexible enough and has overcome the limitations set out by previous international conventions ${ }^{41}$ and opened greater opportunities for the protection of geographical indications in the world. ${ }^{42}$ This is based on the two following points:

First, signs protected as geographical indications are broader than appellations of origin. While appellations of origin are merely direct names indicating geographical places, geographical indications may be indirect names or indirect signs, such as images or symbols. In fact, the TRIPS agreement has no requirement for indications to be a geographical names ${ }^{43}$, allowing one name which is not a geographical name to be used for geographical indication, such as Chaiya salted eggs (Thailand) ${ }^{44}$. Geographical name, it can be the name of a country (Singapore, Thai's), of a territory or just a city, a region (Nakonchaisri Pomelo of Thailand or Sarawak Pepper of Malaysia), the name of a mountain (Ngoc Linh ginseng of Vietnam), a valley, an island (Phu Quoc fish sauce of Vietnam) or any place. The TRIPS agreement does not exclude iconic symbols or images ${ }^{45}$ having a connection with certain locations, as

\footnotetext{
39 The term "indication of source" is used in Paris Convention 1883 and Madrid Agreement 1891 but there is no definition in those two treaties. Article 1(1) of the Madrid Agreement contains language that clarifies what is meant by the term. The indication of source relates to the geographical origin of a product and not to another kind of origin, for example, an enterprise that manufactures the product. This definition does not imply any special quality or characteristics of the product on which an indication of source is used.

${ }^{40}$ See TRIPs Agreement, Art 22.1.

${ }^{41}$ Le (2011), Protection of Geographical Indications in the context of Vietnam's international economic integration, Information and Communication Publishing House, August 2011

${ }^{42}$ Rangnekar Dwijen (2003), The social economic of Geographic Indications: the review of empirical of evidence from Europe, UNCTAD/ICTSD Capacity Building Project on IPR and Sustainable Development

${ }^{43}$ O'Connor Bernard (2003), The Laws of Geographical Indications, Cameron and May Publishing, London, page 52.

${ }^{44}$ Latha R. Nair \& Rajendra Kumar (2005), Geographical Indications: a search for identity, 2005, LexisNexis Butterworths, p. 95.

${ }^{45}$ O’Connor Bernard, op.cit, p52
} 
the Eiffel Tower to designate French good or Twin towers to designate a good from Malaysia.

Second, this definition clearly excludes indications of source which do not specify any quality, reputation or other characteristics of the product but just the geographical source of such products. This requirement for the link between product quality and the geographical origin for geographical indications is lighter than the one requested for appellation of origin. ${ }^{46}$ Indications having one among the three above factors such as only reputation can be protected as a geographical indication.

Among Philippines, Myanmar and Brunei, only the Philippines includes geographical indications in the enumeration of recognized forms of IPRs but does not give any definition of this subject. ${ }^{47}$

The definition of geographical indication in Thailand, ${ }^{48}$ Malaysia, ${ }^{49}$ Indonesia, ${ }^{50}$ Singapore, ${ }^{51}$ Cambodia, ${ }^{52}$ Laos $^{53}$ and Vietnam conforms to that of TRIPS with some differences in form of expression.

\footnotetext{
${ }^{46}$ In the Lisbon Agreement 1958, "appellation of origin" means the geographical name of a country, region, or locality, which serves to designate a product originating therein, the quality and characteristics of which are due exclusively or essentially to the geographical environment, including natural and human factors.

${ }^{47}$ Intellectual Property Code of the Philippines 1997, Section 4: "The term "intellectual property rights" consists of: a.Copyright and Related Rights; b.Trademarks and Service Marks; c.Geographic Indications; d.Industrial Designs; e.Patents; f. Layout-designs (Topographies) of Integrated Circuits; and g.Protection of Undisclosed Information"

${ }^{48}$ The Geographical Indications Protection Act of Thailand, chapter 1, section 3: "Geographical Indication means name, symbol or any other thing which is used for calling or representing a geographical origin and can identify the goods originating from such geographical origin where the quality, reputation or other characteristic of the goods is attributable to the geographical origin"

49 The Geographical Indications Act 2000 of Malaysia, chapter 1, section 2: "geographical indication" means an indication which identifies any goods as originating in a country or territory, or a region or locality in that country or territory, where a given quality, reputation or other characteristic of the goods is essentially attributable to their geographical origin"

${ }^{50}$ The Law of The Republic of Indonesia 2007, Article 1.1 “A Geographical Indication shall mean a sign which indicates the place of origin of a good, which due to its geographical environment factors the nature, the people, or the combination thereof gives specific characteristics and quality on the goods produced therein".

${ }^{51}$ Geographical Indication Act 1998 of Singapore, Article 1: "geographical indication means any indication used in trade to identify goods as originating from a place, provided that (a) the place is a qualifying country or a region or locality in the qualifying country; and (b) a given quality, reputation or other characteristic of the goods is essentially attributable to that place"

52 The Law on Geographical Indications 2009 of Cambodia, Article 4: "Mark of Goods which include a Geographical Indicationrefers to a name, symbol or any other sign which is used fo
} 
The definitions in Vietnamese law require both the existence of natural and human factors for geographical indications, with either raw material be sourced locally or any influence of the climate or natural elements must be demonstrated. ${ }^{54}$ The definition of geographical indication in Indonesian law provides that geographical environmental factors, which are the natural factors and/or the human factors, can be taken alone or in combination to justify the specific characteristics and quality of the goods bearing the geographical indication. ${ }^{55}$ Human factors taking alone mean geographical indication can be protected for processed goods made out of non-local raw materials.

Geographical indications in TRIPS Agreement is open for any kind of goods so it is in all ASEAN countries, ${ }^{56}$ with legislations in some countries like Thailand ${ }^{57}$, Malaysia $^{58}$ and Singapore ${ }^{59}$ which have incorporated such a wide a range of goods as natural, agricultural, handicraft and industrial products. The new drafted Rule and Regulation on Geographical Indications of the Philippines extends the protection for agricultural products, foodstuff, any products of handicraft, or wines and spirits in the same way as Thailand, Malaysia and Singapore do ${ }^{60}$.

$\mathrm{r}$ calling or representing a geographical origin and canidentify the goods as originating in such geographical origin wher e the quality, reputation orother characteristic of the goods is essentially attributable to the geographical origin"

${ }^{53}$ The Law on Intellectual Property 2011 of Lao, Article 4.22: "Geographical indication means a sign used to indicate a good as originating in the territory of a country or region or locality in that territory, where a given quality and reputation or other characteristic of the good is essentially attributable to its geographical origin"

${ }^{54}$ The Law on Intellectual Property of Vietnam, Article 82.2 and Article 82.3.

${ }^{55}$ The Law of The Republic of Indonesia 2007, Article 1.1: “A Geographical Indication shall mean a sign which indicates the place of origin of a good, which due to its geographical environment factors the nature, the people, or the combination thereof gives specific characteristics and quality on the goods produced therein."

${ }^{56}$ Marie-Vivien, Delphine, The Protection of Geographical Indications for Handicrafts: How to Apply the Concepts of Natural and Human Factors to All Products, WIPO Journal 4, no. 2 (2013), 191-203

${ }^{57}$ The Geographical Indications Protection Act of Thailand, chapter 1, section 3: "Goods" means articles which can be traded, exchanged or transferred, whether they are natural or are agricultural produces, including handicraft and industrial products

${ }^{58}$ The Geographical Indication Act 2000 of Malaysia, chapter 1, section 2: "goods" means any natural or agricultural product or any product of handicraft or industry

59 The Geographical Indication Act 1999 of Singapore, Article 2: "goods" means any natural or agricultural product or any product of handicraft or industry

${ }^{60}$ The drafted Rule and Regulation on Geographical Indication 2014 of the Philippines, Article 1, Rules 2(b) 
While the law in Vietnam, Indonesia, Cambodia and Lao are silent on this issue, with no restriction, it means that any kind of goods are protected as geographical indications in these countries. Examples of geographical indication for handicraft goods are Non Hue (Vietnam), or Aranyik knives, Chantaburi sapphire, and Sukhotai gold (Thailand).

Thus, this is evident from this insight that the ten ASEAN countries have attempted to satisfy the definition of geographical indication stipulated in the TRIPS Agreement but each has a different provisions and even a different requirement regarding the strength of the link with the origin, with the combination of natural and human factors being facultative or mandatory.

\section{Homonyms}

Homonyms are the geographical names identical in respect of spelling or pronunciation but designate different geographical areas, within a country or in different countries. ${ }^{61}$ Article 22.4 of TRIPS Agreement requires each WTO Member to determine the practical conditions under which the homonymous indications will be differentiated from each other, taking into account the need to ensure equitable treatment of the producers concerned and that consumers are not misled.

Almost all of ASEAN countries' laws exclude homonymous indications from protection, while Indonesia and Vietnam are silent on this issue. Malaysia ${ }^{62}$ and Singapore $^{63}$ expressly extend protection to homonymous indications of wines only. Thailand extended protection not only of wine but also of the additional categories to

\footnotetext{
${ }^{61}$ O’Connor (2004), op.cit, p. 104

${ }^{62}$ The Geographical Indication Act 2000 of Malaysia, Section 7.1 "In the case of homonymous geographical indications for wines, protection shall be accorded to each indication".

${ }^{63}$ The Geographical Indications Act 1999 of Singapore, Section 3.2(c) “.... any use of a geographical indication, being a geographical indication which identifies a wine, in relation to a wine which did not originate from the place indicated by the geographical indication"
} 
which they are offering protection similar to wines and spirits. ${ }^{64}$ In Vietnam, there is no prohibition on registration of homonymous indications, some homonymous indications could be protected after considering the practical conditions under which each indication could be differentiated or under the FTAs which Vietnam is signatory. ${ }^{65}$

For ASEAN countries protecting geographical indication through trademark regime, it is assumed that homonymous indications could not be protected under this system even in relation to wines as mandated by TRIPS. ${ }^{66}$

\section{Generic names}

The provision in Article 24.6 of TRIPS provides an exception to obligation of protecting geographical indications for WTO Members if that indication is 'identical with the term customary in common language as the common name' for the goods or services in question in that Member, i.e. has become the generic term for describing the goods or services in the local language.

ASEAN countries adopt the TRIPS provision, thus making generic or customary geographical indications not protectable in ASEAN. ${ }^{67}$ It is the case of Thai Hom Mali rice or jasmine rice (Thailand) which has not been registered in EU, instead Thung Kula Rong-Hai is protected as geographical indication in this market. It means that Thailand cannot forbid traders in the EU from importing and packaging in the EU varieties of Thai jasmine rice grown in other areas of Thailand. ${ }^{68}$

\footnotetext{
${ }^{64}$ The Geographical Indications Protection Act of Thailand, Section 29 "In case that the specific goods [...] have the same or homonymous geographical indication but different geographical origin, when registration of a geographical indication for those goods is effected, the use of geographical indication in this case shall be in accordance with the rules and procedures prescribed in Ministerial Regulations".

${ }^{65}$ This is the case of homonym Pisco. Pisco is granted as geographical indication for Peru in 2007, then is also recognized as protected geographical indication in the Vietnam-Chile FTA in 2014

${ }^{66}$ Gopalakrishnan, N.S. et al (2007)

${ }^{67}$ Thitapha Wattannapruttipaisan (2009), Trademark and Geographical Indications: Policy issues and Options in Trade Negociations and Implementation, Asian Development Review, vol. 26, no. 1.

${ }^{68}$ Chuthaporn Ngokkuen and Ulrike Grote, op.cit., p110
} 
The question of generic geographical indication is addressed in FTAs, because generic notion interpretation is different in Member jurisdictions. ${ }^{69}$ Countries usually undertake to phase out the generic use of geographical indication as an important quid pro quo for advancing negotiations in other areas. ${ }^{70}$ For example, EU has made efforts to repatriate some 41 names (with 28 for wines and spirits) such as Champagne that was successfully protected in ASEAN countries including Thailand, Malaysia, Indonesia, Myanmar and Vietnam.

\section{Means of protection}

The TRIPS Agreement does not provide any specific regulation towards the legal means for geographical indication protection. Three legal systems in three groups of countries are recorded with regards to this matter. The EU which has a long tradition of geographical indications protection has a sui generis system, i.e. a register for geographical indications, an substantive examination of the validity of the geographical indication (the existence of the link with the origin), an opposition procedure, the right of use for all those who comply with the geographical indication specification. Countries such as the US, Canada and New Zealand protect geographical indications through an existing system of collective marks and certification marks, which are governed under trademark law i.e. with the criteria of availability of the term. In addition, geographical indications are also protected under business law and unfair competition law.

Almost all ASEAN countries having a long traditional relationship with the EU have followed the sui generis approaches for geographical indication and a registration system. Only Philippines, Myanmar and Brunei provide protection of geographical

\footnotetext{
${ }^{69}$ Evans G.E. and Michael B. (2006), The protection of geographical indications after Doha: quo vadis?, Journal of International Economic Law, 1 of 40

${ }^{70}$ Ibid
} 
indication through trademark system. ${ }^{71}$ Yet they are in the process of enacting sui generis law. Singapore affords protection through either specific geographical indication law or trademark law and passing off ${ }^{72}$ but there is no system of registration.

\section{Scope of protection}

The scope of protection under the TRIPS Agreement distinguishes between the minimum standard for geographical indications related to all products (Article 22.2) and a higher level of protection for wines and spirits (Article 23.2) and an extraadditional protection only for wines (Article 23.1). ${ }^{73}$

\section{- Minimum standard for all GIs}

TRIPs agreement requires WTO Members to provide legal means for the prevention of "the use of any means in the designation or presentation of a good that indicates or suggests that the good in question originates in a geographical area other than the true place of origin in a manner which misleads the public as to the geographical origin of the good" and "any use which constitutes an act of unfair competition" under Article 10bis of the Paris Convention. This general protection aims at the prevention of misleading indications and unfair competition involving the registration of a GI. The legal means for obtaining defensive protection would mainly be through unfair competition laws, common law rules on passing off or case law. ${ }^{74}$ This approach has developed historically, ${ }^{75}$ starting out from the limited prohibition to use false indications of source only in cases where they were used together with false trade names in the Paris Convention, evolving to a prohibition of the use of false and deceptive indications of source in the Madrid Agreement on Indications of Source and

\footnotetext{
${ }^{71}$ See Table 1

${ }^{72}$ The Law on Geographical Indications 1998 of Singapore, section 12 "Nothing in this Act shall affect the rights of a person under the Trade Marks Act 1998 or the law relating to passing off"'

${ }^{73}$ The TRIPs Agreement, Art 22.2, 23.2 and 23.1

${ }^{74}$ Sisule F. Musungu (2008), The protection of Gl and the Doha Round, QUNO, p14

${ }^{75}$ Gopalakrishnan, N.S. et al (2007) op.cit, p22
} 
to a general prohibition of the use of geographical indication which constitutes an act of unfair competition within the meaning of Article 10bis of the Paris Convention.

It is evident that all the ASEAN countries provide general framework for all Gis through different regimes, either sui generis or trademark law and unfair competition law. But Thailand ${ }^{76}$ and Indonesia ${ }^{77}$ granted protection against the unlawful uses. While Vietnam $^{78}$, Singapore ${ }^{79}$, Cambodia ${ }^{80}$ and Laos ${ }^{81}$ defined prohibited acts or uses of unfair competition and consumer deception. Yet Malaysia ${ }^{82}$ describes them as acts against which injunction and damages could be claimed.

\section{- Higher level of protection for wines and spirits}

Article 23 of the TRIPs Agreement requires WTO Members to provide legal means for "interested parties to prevent use of a geographical indication identifying wines for wines not originating in the place indicated by the geographical indication in question or identifying spirits for spirits not originating in the place indicated by the geographical indication in question, even where the true origin of goods is indicated or the geographical indication is used in translation or accompanied by expressions such as "kind", "type", "style", "imitation" or the like." The main difference between the two level of protection remain at notion of 'misleading the public'. The removal of the requirement of misleading the public means that GIs owners for wines and spirits are entitled to protection even when use of the geographical name would not mislead the public or constitute an act of unfair competition; and even in cases where the true origin of the product is indicated.

\footnotetext{
${ }^{76}$ The Geographical Indications Protection Act of Thailand, Section 27

77 The IP Code of the Philippines, Section 57

${ }^{78}$ The Vietnam Law on Intellectual Property, Article 130

${ }^{79}$ The Geographical Indication Act 1999 of Singapore, section 3(1) and (2)

${ }^{80}$ The Law on Geographical Indications of Cambodia, Article 12

${ }^{81}$ The Law on Intellectual Property of Lao, Article 120

${ }^{82}$ The Geographical Indication Act 2000 of Malaysia, section 5
} 
The additional protection for wines and spirits seems to be confined to these two categories only in the law of Vietnam ${ }^{83}$, Malaysia ${ }^{84}$, Singapore ${ }^{85}, \operatorname{Laos}^{86}$. Thailand permits Minister to specify any goods as specific goods benefiting from additional protection by the issue of a Ministerial Regulation. ${ }^{87}$ Indonesia and Cambodia grant additional protection to all kind of goods. Yet in some countries, the interpretations of these provisions are not yet clear since the law is only at an early stage of implementation and there has been no case law. Moreover, with the negotiations on extending the additional protection to all products at the WTO ${ }^{88}$ domestic legal framework might evolve to remove this divide.

In the controversial debate between WTO's members on the different level of protection between geographical indications for wines and spirits and those for other products. It is interesting that the TRIPS definition of geographical indications does not distinguish between products and, therefore, constitutes both a premise and a precedent of harmonious, balanced protection of all geographical indications on all products alike. For ASEAN countries, almost are non-wine producing, so they are in

\footnotetext{
${ }^{83}$ The Vietnam Law on Intellectual Property 2009, Article 129.3.d prohibits "Using protected geographical indications of wines or spirits for wines or spirits not originating from geographical areas bearing such geographical indication, even where the true origin of goods is indicated or geographical indications are used in the form of translations or transcriptions, or accompanied by such words as "category," "model," "type," "imitation" or the like"

${ }^{84}$ The Geographical Indication Act 2000 of Malaysia, section 5.1.d prohibits "any use in the course of trade of a geographical indication identifying wines for wines not originating in the place indicated by the geographical indication in question or a geographical indication identifying spirits for spirits not originating in the place indicated by the geographical indication in question, even where the true origin of the wines or spirits is indicated or the geographical indication is used in translation or accompanied by expressions such as "kind", "type", "style" or "imitation"

${ }^{85}$ The Geographical Indications Act 1999 of Singapore, section 3.2.c \& 3.2.d prohibit "any use of a geographical indication, being a geographical indication which identifies a wine/spirit, in relation to a wine/spirit which did not originate from the place indicated by the geographical indication"

${ }^{86}$ The Law on Intellectual Property 2011 of Lao, Article 59.2 prohibits "a geographical indication [...] where related to wines or spirits, even in translation or accompanied by expressions such as "kind", "type", "style", "imitation" or the like

${ }^{87}$ The Geographical Indications Protection Act of Thailand, section 28 "Indication of the true geographical origin of the goods [...] shall include the use of the expressions "kind", "type", "Style" including any similar expression or the like in conjunction with the geographical indication used with the goods.

${ }^{88}$ See WT/GC/W/546, available at https://www.wto.org/english/tratop_e/trips_e/ta_docs_e/5_2_wtgcw546_e.pdf and TN/C/W/25, available at https://www.wto.org/english/tratop_e/trips_e/ta_docs_e/5_2_wtgcw546_e.pdf
} 
favour of extending protection in line with Article 23(1) to products other than wines and spirits. ${ }^{89}$

\section{- Extra-additional protection only for wines}

Article 23 provides a mandate for the Council for TRIPS to undertake negotiations on the establishment of a multilateral system of notification and registration of GIs for wines eligible for protection in the Members participating in the system.

In 2001 during the Doha Round of TRIPS negotiations, the WTO Member States committed to reach an agreement on the creation of the Multilateral Register by the 5th Ministerial Conference to take place in Cancun in September of 2003. While the Doha Ministerial Declaration explicitly launches negotiations on establishing a multilateral system of notification and registration of GIs for wines and spirits, WTO Members are still debating whether negotiations are also mandated for the extension of the protection of GIs for products other than wines or spirits.

Thus, the WTO meeting in Cancun came and went without any agreement on a Multilateral Register. Since Doha, there has been absolute gridlock ${ }^{90}$ on this issue, largely the result of the vastly divergent positions taken by the EU and US.

For relation with trademarks, the TRIPS obligation on geographical indications is only to provide an effective means for the protection of geographical indications. Members have enough flexibility to design a system of protection in line with TRIPS, this leads to a conflict of rights between geographical indication and trademark protections. The TRIPS Agreement provides a framework for the resolution of this conflict in Article 24.5. However, Article 24 can be interpreted as an exception of both trademark and geographical indication, two equal subjects of IPRs under TRIPS

\footnotetext{
${ }^{89} \mathrm{WT} / \mathrm{GC} / \mathrm{W} / 546$ and $\mathrm{TN} / \mathrm{C} / \mathrm{W} / 25$.

${ }^{90}$ Malobika Banerji, op,cit.
} 
agreement. This results in different interpretations in local jurisdictions according to their respective views on the matter. ${ }^{91}$

For countries of trademark system, the principle "exclusive rights of a trademark registered previously in a good faith" in article 16.1 is applied, so the registration of a geographical indication identical or similar to an earlier registered trademark for an identical or similar product will be rejected to avoid confusion. In this case, the protection of a geographical name can be made by the registration of certification marks, provided that the use of this indication is fair and that such exceptions take into account the legitimate interests of the trademark owner and of third parties ${ }^{92}$. This is the case of Binh Thuan for dragon and PhuQuoc for fish sauce (Vietnam) or Thai Hom Mali Rice (Thailand) ${ }^{93}$.

The European Union countries confirm that Article 24.5 of the TRIPs Agreement on the exception of geographical indications protection over trademarks allows the coexistence of an early registered trademark and a similar or identical geographical indication protected later. A registered trademark can only prevent a geographical indication to be registered later if a trademark has been used and has achieved a certain prestige $^{94}$. If the trademark has not acquired any reputation, the geographical indication is still accepted for registration, which leads to the coexistence of trademarks and geographical indications. This means that a pre-registered trademark still will be used but it loses its monopoly when a geographical indication identical or similar to a product trademark is protected ${ }^{95}$. Thus, the European Union applies the principle of the coexistence of a pre-registered trademark and a geographical indication similar or identical to the trademark protected later. The ASEAN sui

\footnotetext{
${ }^{91}$ Le (2013) Conflit de protection de l'indication géographique et de la marque selon l'Accord ADPIC et le droit vietnamien, in «EU ASEAN Partenariat », FEDUCI collection, Sweet \& Bruylant Publisher, 2013

${ }^{92}$ Grevers F., "Topical issues of the protection of geographical indication", 1999.

${ }^{93}$ Refer to: http://www.uspto.gov

${ }^{94}$ For instance, Tabasco, a province name in Mexico is registered as the trademark of a sauce product.

${ }^{95}$ Regulation No 510/2006 of the European Union - Article 14.
} 
generis countries apply "first to file" to the protection of trademarks and geographical indications and accept the coexistence of trademarks registered previously in good faith and geographical indications later registered.

The ASEAN sui generis countries apply "first to file" to the protection of trademarks and geographical indications and accept the coexistence of trademarks registered previously in good faith and geographical indications later registered. However, Thailand is a unique ASEAN country in the proposals submitted by the EU to WTO ${ }^{96}$ while the Philippines have supported the US's approach. ${ }^{97}$

Beside the need for ASEAN countries to improve geographical indication protection system at home first to answer to challenges, there is a need to better build interoperability with several options that can be considered.

\footnotetext{
${ }^{96}$ Thailand is a signatory to EU's proposals submitted to WTO: JOB(02)/194; TN/C/W/14 and Add.1 and 2, and Corr.1; WT/GC/W/540/Rev.1 and Add.1 TN/C/W/21/Rev.1 and Add.1; JOB(05)/61 and Add.1-2; see WT/GC/W/546, TN/C/W/25,18 May 2005, available at: https://www.wto.org/english/tratop_e/trips_e/ta_docs_e/5_2_wtgcw546_e.pdf last accessed on 12/12/2016

${ }^{97}$ Philippines is a signatory to US'proposals submitted to WTO IP/C/W/386; IP/C/W/360, see WT/GC/W/546, TN/C/W/25,18 May 2005, available at: https://www.wto.org/english/tratop_e/trips_e/ta_docs_e/5_2_wtgcw546_e.pdf, last accessed on 12/12/2016
} 


\section{CHAPTER II: EXISTING PROTECTION FRAMEWORK FOR THE PROTECTION OF GEOGRAPHICAL INDICATIONS AT THE INTERNATIONAL AND REGIONAL LEVEL}

The first international intellectual property treaties, the Paris Convention in 1883, Madrid Agreement and Lisbon Agreements including its new Geneva Act have made considerable efforts to develop the multilateral framework for the international protection of geographical indications, i.e. the protection of domestic geographical indication in foreign jurisdictions, in order to accompany the increase of the global trade of geographical indication products (I). While the international registration system at WTO level may remain a long-term objective, some countries have started to engage into regional framework, building up interoperability system to facilitate the protection of geographical indications among them. It is interesting to analyse those systems and see whether they can facilitate the protection of geographical indications in ASEAN countries (II).

\section{International notification and registration system of Geographical Indications}

1. The freeze in the international negotiations TRIPS

The principle under TRIPS Agreement for the international protection of geographical indications is that in order for the domestic geographical indication to be protected in the export country, it is needed to request the protection in such country, according to its legislation. To avoid such heavy and numerous procedures, TRIPS Agreement provides for the negotiations towards the establishment of a multilateral system of notification and registration of geographical indications for wines, later extend to spirits. This mandate is clearly given in Article 23 (4) of the 
TRIPS Agreement and in the Doha Declaration. ${ }^{98}$ Those negotiations began in 1997 and were later included in the Doha Round in 2001, dating back nearly 20 years ago.

TRIPS agreement provides that mandate but does not set out a timeframe for the completion of the negotiations and indicate that participation in the system may be voluntary. That leads to divergence between countries. Some countries are of the view that there is no agreement to negotiate other outstanding implementation issues. ${ }^{99}$ Other countries take the position that there is a clear mandate to negotiate the issue. ${ }^{100}$ The three main different proposals are put forth by the EC, US and Hong Kong.

The United States has assumed the responsibility of supervising the minimum proposal known as the joint proposal (the name is based upon the large number of countries that support it). ${ }^{101}$ It is influenced by the trademark system, with the basic principle of creating a database of geographical indications from different countries. Participation is entirely voluntary, and the database will contain information on the name protected as a geographical indication, the concerned WTO member, the date on which the geographical indication was protected by the member, the expiration date, and if applicable, any agreement involved, ${ }^{102}$ and the identification of the area

\footnotetext{
${ }^{98}$ With a view to completing the work started in the Council for Trade-Related Aspects of Intellectual Property Rights (Council for TRIPS) on the implementation of Article 23.4, we agree to negotiate the establishment of a multilateral system of notification and registration of geographical indications for wines and spirits by the Fifth Session of the Ministerial Conference. See Paragraph 18 of the Doha Declaration.

${ }^{99}$ See Communication from Argentina regarding paragraphs 18 and 12 of the Draft Ministerial Declaration, 12November 2001, WT/MIN.(01)/W/8, available at http://www/wto.org/, last accessed on 12/12/2016

${ }^{100}$ See Communication from Bulgaria, Czech Republic, EU, Hungary, Liechtenstein, Kenya, Mauritius, Nigeria, Pakistan, The Slovak Republic, Slovenia, Sri Lanka, Switzerland, Thailand and Turkey regarding paragraphs 18 and 12 of the Draft Ministerial Declaration, 14 November 2001, WT/MIN(01)/W/11, available at http://www.wto.org/, last accessed on 12/12/2016

${ }^{101}$ The groupof the proposed joint proposal hasfluctuatingcontoursand has increased significantly.Japan signed the first proposal submitted in 1999 (IP/C/W/133) with the United States and will be part of the 17 signatories countries of the proposal of 2002 (IP/C/W/5, 23 October 2002) : Argentina, Australia, Canada, Chile, Colombia, Costa Rica, El Salvador, Ecuador, the United States, Guatemala, Honduras, Japan, Namibia, New Zealand, the Philippines, the Dominican Republic, and China have not, but will sign the last proposal of 2005

${ }^{102}$ See IP/C/W/5, 23 October 2002, available at https://www.wto.org/english/tratop_e/trips_e/ipcw5_e.doc last accessed on $12 / 12 / 2016$
} 
relevant to the geographical indication. These points appear to be the basic minimum of what defines a geographical indication. ${ }^{103}$

Any objection is resolved at the national level because it is not considered necessary to establish a new procedure for resolving disputes internationally. ${ }^{104}$ The only requirement for members who choose to be part of the system is to refer to the notified list of geographical indications while referring to other sources of information. ${ }^{105}$ The joint proposal is based on a tradition of protecting geographical indications through the trademark system and constructs a multilateral system that is minimally least constraining, meaning that geographical indication applicant from origin country needs to proceed all the procedure for protection of their geographical indication abroad in every single country where the protection is sought after.

On the other hand, the maximum concept of protection is set forth under the Lisbon Agreement and the European mechanism. ${ }^{106}$ The first EU (1998) proposal outlined a multilateral system, which necessarily involved all WTO members, with all the existing geographical indications being already recognized and protected in their country of origin, along with applicable laws and proof of compliance according to the definition of the geographical indication. ${ }^{107}$ This notification of a list was followed by a proposed notification of individual geographical indications that was similar to the joint proposal, but which also provided for the notification of available translations of the geographical indication, and a mention of the legal instrument under which the geographical indication is protected.

\footnotetext{
${ }^{103}$ See IP/C/W/10, $1^{\text {er }}$ April 2005

104 See TN/IP/W/9, 13 April 2004

${ }_{105}$ See $\quad$ IP/C/W/133, $11 \quad$ March $1999, \quad$ available at https://docsonline.wto.org/dol2fe/Pages/SS/DirectDoc.aspx?filename $=\mathrm{t} \% 3 \mathrm{~A} \% 2 \mathrm{Fip} \% 2 \mathrm{Fc} \% 2 \mathrm{Fw} 133$.doc\&, last accessed on $12 / 12 / 2016$

${ }^{106}$ Evans and Blakeney, The Protection of Geographical Indications after Doha: Quo Vadis?, p607.

107 See IP/C/W/107, 28 juillet $1998, \quad$ available at https://docsonline.wto.org/dol2fe/Pages/FormerScriptedSearch/directdoc.aspx?DDFDocuments/t/IP/C/W107.doc, last accessed on 12/12/2016
} 
The EU proposal regarding an objection is in stark contrast to the joint proposal, in that the differences and objections are resolved at an international level through direct negotiations between the concerned countries in terms of absolute grounds of refusal, known as reserves, the relative grounds of refusal having been resolved at the national level. Possible reasons for absolute refusal include noncompliance of the geographical indication with the definition of the TRIPS Agreement (Art.22.1), the question of homonyms (Art.22.4) and the generic nature of the geographical indication (Art.24.6). Relative grounds include the existence of prior rights (Art.24.4 and 24.5). These cannot form the basis of a reservation at the international level by the WTO members, but they can be invoked under domestic law. ${ }^{108}$

The system implies a two-tier logic of examination. Acceptance of an application, after success at the first stage of the examination of absolute criteria at the international level, reduces further questions about the validity of the geographical indication (related to these criteria) in each country where protection is sought. These legal effects apply to all WTO members, regardless of whether they are a part of the system or not. However, the obligations of the participating members go beyond this: the registration of a geographical indication on the multilateral register constitutes a rebuttable presumption of its eligibility for protection.

Hong Kong shares this concept of rebuttable presumption and has made a "middle" proposal. This proposal is based on an entirely voluntary principle of participation, just as in the joint proposal. Any conflict between competing geographical indications is settled at the national level, in the same way as for joint proposals. Registration would provide prima facie evidence of ownership of the geographical indication, its conformity with the TRIPS Agreement, and the protection it enjoys in the country of origin. ${ }^{109}$ The presumption does not apply to the recognition of geographical

\footnotetext{
${ }^{108}$ See TN/IP/W/11, 14 juin 2005

${ }^{109} \mathrm{See} \mathrm{TN} / \mathrm{IP} / \mathrm{W} / 8,23$ avril 2003
} 
indications as a non-generic name or to the issue of homonyms. All other grounds of validity of a geographical indication would be dealt with at the national level, leaving little scope to move to the international sphere.

At the last WTO meeting in Cancun no agreement on a Multilateral Register was reached. Since Doha, there has been absolute gridlock ${ }^{110}$ on this issue, largely the result of the vastly divergent positions taken by the EU and US. It means that under TRIPS Agreement, there is no facilitation system for the protection of geographical indications at the international level that could help protection of geographical indications within ASEAN countries.

\section{The new-born Geneva Act of the Lisbon Agreement}

The Lisbon Agreement, as adopted in 1958 and revised in 1967, provides a single international registration system for appellations of origin, administered by International Bureau of WIPO. The principle is that appellation of origin of each of the signatories' countries are automatically protected in all the signatories' countries except in the country who have opposed to it in a delay of one year. As domestic legislations of many countries do not incorporate the concept of "appellations of origin" with parallel provisions, Lisbon Agreement did not attract many Members other than 28 countries, not even including all the EU countries. Indeed, the definition of appellation of origin sets higher criteria for recognition than those for geographical indication defined in TRIPS. ${ }^{111}$

Taking the shortcomings of the Lisbon Agreement into consideration, the Geneva Act of the Lisbon Agreement, as adopted in May 2015, expands the application of the

\footnotetext{
${ }^{110}$ Malobika Banerji, op, cit

${ }^{111}$ Art. 2.1(i) of Geneva Act defines AO is 'any denomination protected in the Contracting Party of Origin consisting of or containing the name of a geographical area, or another denomination known as referring to such area, which serves to designate a good as originating in that geographical area, where the quality or characteristics of the good are due exclusively or essentially to the geographical environment, including natural and human factors, and which has given the good its reputation'
} 
system to geographical indications as defined in the TRIPS Agreement; thus, enlarges the system to denomination of products having a weaker link with their geographical origin than those with appellation of origin. The definitions of geographical indication and appellation of origin laid down in Article 2.1, includes any words "consisting of or containing the name of geographical area, or another denomination known as referring to such area". As for TRIPS, Lisbon is now more flexible in the sense that geographical indication/appellation of origin does not necessarily designate a real place but just a name "known as referring to" such place.

Lisbon system is characterized by the creation of a special Union for the registration of already protected at national level appellation of origin/geographical indication in an International Register which automatically confers the high level of protection granted to geographical indication/appellation of origin by the Lisbon system to all parties of the Agreement, except in the contracting party which has refused the registration during the time limit provided by the Regulations.

Article 11 of the Geneva Act maintains the high level of protection of the initial Lisbon Agreement, which has inspired the additional protection for wines and spirits of the TRIPS Agreement, while providing more details about the content of the protection.

The Geneva Act prohibits any use of the geographical indication/appellation of origin in respect of goods of the same kind not originating in the geographical area of origin or not complying with any other applicable requirements for using the geographical indication/appellation of origin (such as specification), without having to prove any risk of misleading. It also prohibits the use for dissimilar goods, if such use would indicate or suggest a connection between those goods or services and the beneficiaries of geographical indication/appellation of origin, and would be likely to damage their interests, or, where applicable, because of the reputation of the 
geographical indication/appellation of origin the Contracting Party concerned, such use would be likely to impair or dilute in an unfair manner, or take unfair advantage of, that reputation. Any other practice liable to mislead consumers as to the true origin, provenance or nature of the goods is also prohibited.

The Geneva Act also prohibits any imitation of the geographical indication/appellation of origin, even if the true origin of the goods is indicated, or if the geographical indication/appellation of origin used in translated form or is accompanied by terms such as 'style', 'kind', 'type', 'make', 'imitation', 'method', 'as produced in', 'like', 'similar' or the like.

Regarding later trademark, a Contracting Party shall, ex officio if its legislation so permits or at the request of an interested party, refuse or invalidate the registration of a later trademark if use of the trademark would result in one of the situations covered by article 11 .

An innovation from the initial Lisbon Agreement is that the application for international registration can be done by the Competent Authority of the Party or directed by the beneficiaries of the geographical indication/appellation of origin, i.e. the producers. This reflects the influence of TRIPS where the protection in foreign jurisdiction can be applied by the users of the geographical indication.

In conclusion, the Geneva Act of the Lisbon Agreement is a very interesting tool to facilitate the protection of domestic geographical indications in countries members of the Union. As written by D. Gervais, the system is very appealing as it allows for objections against the registration for any reason. ${ }^{112}$ Yet even if now it is easier for any country to become member of the Lisbon System, yet, it will take time before

${ }^{112}$ Daniel J. Gervais, Traditional Knowledge: Are We Closer to the Answers? The Potential Role of Geographical Indications, ILSA Journal of International and Comparative Law 15, no. 2 (2009), p564. 
new countries join while at the moment none of the ASEAN countries or the ASEAN itself is its member.

\section{Existing regional registration system of Geographical Indications}

With very few countries member of the Lisbon Union and TRIPS Agreement not really offering any facilitation for international protection of geographical indications, some group of countries have decided to set up regional system for the protection of geographical indications. In particular, the EU, having a full-integrated system, but also the West-African countries of African Intellectual Property Organisation (OAPI).

\section{EU System}

The EU system created in $1992^{113}$, already largely described, provides a completely integrated system at the level of the EU. It grants unique legal title valid for all countries members of the EU, replacing the geographical indications at the national level, which are only transitional, granted the time for the domestic geographical indication to be registered at the EU level. This system was set up to support the common market and the free circulation of goods within that market. While wines ${ }^{114}$, spirits $^{115}$ and agricultural products and foodstuffs ${ }^{116}$ can enjoy unitary protection granted exclusively at EU level, no specific geographical indication system is operated at EU-level for non-agricultural products which are only protected through various national legal frameworks. ${ }^{117}$

\footnotetext{
${ }^{113}$ There are two EC Council Regulations, "Council Regulation 2081/92 on the protection of GIs and designation of origin for agriculture products and foodstuffs", JO L208, 24/07/1992, p1 and "Council Regulation 2082/92 of 14 July 1992 on certificates of specific character for foodstuffs", JO L208, 24/07/1992, p9

${ }^{114}$ Regulation (EC) No 479/2008 on the common organisation of the market in wine

${ }^{115}$ Regulation (EC) No 110/2008 on the definition, description, presentation, labelling and protection of geographical indications of spirit drinks

${ }^{116}$ Regulation (EC) No 510/2006 on the protection of geographical indications and designations of origin for agricultural products and foodstuffs and Regulation (EU) No 1151/2012 on quality schemes for agricultural products and foodstuffs

${ }^{117}$ EU Member States' laws on protecting non-agricultural GIs have not yet been harmonised. All Member States protect non-agricultural products by laws on unfair competition or consumer deception. Only 15 Member Statesprovidesui generis systems forprotecting non-agricultural GIs(Belgium, Bulgaria, Croatia, Czech Republic, Estonia, France, Germany, Hungary, Latvia, Poland, Portugal, Romania, Slovakia, Slovenia, Spain (region of Murcia).
} 
The European Union is the world leading producer of wine and would enhance the reputation of European wines and regaining market share both in the EU and outside. The first wine name were protected at EU level under legislation in the 1970s that required Member States to identify and protect geographical indications and notify them to the European Commission and thereby protect them in all Member States. ${ }^{118}$ After reform to the wine sector in 2008, an EU register for wine is established along similar lines as that for agricultural products and foodstuffs and that is in the process of being implemented. An additional list geographical indication has been established for aromatized wines, which is associated with the register for wine names. The first spirits were protected throughout the EU in 1989 legislation ${ }^{119}$ by a list of names in annex to this regulation, which serves as the register. Under Regulation 110/2008 on protection of geographical indications for spirits, there is no specific provision on application at national level but only registration procedure at EU level. Since 2013, wines are protected through EU Reg.1308/2013 following the same principle of a two-step registration procedure as for agricultural goods and foodstuff.

For agricultural products and foodstuffs, however, an EU register was established from the beginning in 1992 and a procedure set in place for applications to be sent to the EU authorities and entered in the register. Once the geographical indication is registered at the EU level, the national transitional rights disappear. Indeed, no national rights shall co-exist next to the EU PDOs and PGIs. The EU system is mandatory for all members of the EU, with no possibility to only grant national PDOs or PGIs for the list of products annexed to the EU Regulation where only the EU is

See more on: http://eur-lex.europa.eu/legal-content/en/TXT/?uri=CELEX:52014DC0469, last accessed on $12 / 12 / 2016$

${ }^{118}$ Frank Fay, "EU system for geographical indications for agricultural products and foodstuffs", WIPO/GEO/SOF/09/4

${ }_{119}$ Regulation (EEC) No 1576/89 of 29 May 1989 laying down general rules on the definition, description and presentation of spirit drinks 
competent. In the same light, only the EU is authorized to negotiate trade agreement on the field of geographical indications and not the members States of the EU. geographical indication is, thus, completely placed under the sovereignty of the EU and not anymore of its member States.

\section{West Africa}

In Africa, among 23 countries with sui generis geographical indication laws, $17^{120}$ are Members of the African Intellectual Property Organization (OAPI) and, therefore, have the same geographical indication law, namely the provisions of Annex VI to the Bangui Agreement ${ }^{121}$. It is, thus, the same unique legislation for IPRs including geographical indication in the 17 countries. All the Member States of the OAPI are party to both the Paris Convention and TRIPS Agreement. Burkina Faso, Congo, Gabon and Togo are also Parties to the Lisbon Agreement. ${ }^{122}$

Under Title III, Annex VI of Bangui Agreement, any person wishing to register geographical indication must file with the Organization or the Ministry responsible for industrial property: (1) an application to the Director General of the Organization, (2) a document on evidence of payment to the Organization of filing fee, (3) geographical area of designation, (4) product for which the indication is used, and (5) quality, reputation or other characteristic of the products in question (Article 7). Upon receipt of the application, the Organization shall examine if the applicant is eligible for applying for such geographical indication protection and whether the requirements set out in Article 5(b) and 7 are met and prescribed fees are paid. If it satisfies all those criteria, the geographical indication shall be registered in the Special Register of geographical indications. Afterwards, the Organization shall

\footnotetext{
${ }^{120}$ Benin, Burkina Faso, Cameroon, the Central Africa, Chad, Congo Republic, DR Congo, Côte d'Ivoire, Gabon, Guinea, Guinea Bissau, Equatorial Guinea, Mali, Mauritania, Niger, Senegal and Togo are Parties to the OAPI Agreement, which embodies the national laws of the Member States of the African Intellectual Property Organisation and, therefore, applies directly in each Member State. See Table 2

${ }^{121}$ Available at $\mathrm{http}: / / \mathrm{www} .0 a p i . i n t /$, last accessed on 12/12/2016

${ }^{122}$ See Table 2
} 
publish the registration and issue a certificate to the owner of the geographical indication. Within six months from that publication, a third party is entitled to oppose the registration of a geographical indication by a written statement. The Organization shall send a copy thereof to the applicant or his agent, who may reply within a oncerenewable period of three months. The reply (if any) shall then be delivered to the opponent or his representative. In case no reply from the applicant is made, he shall be deemed to have withdrawn his application and thus the registration will be cancelled. A process of hearing is also conducted on request, the results from which the Organization shall take into account and give a final decision on whether to grant protection for the geographical indication. Decision on cancellation shall be made public at the Bulletin of the Organization. A member of OAPI can also request the application to be filed before its national competent authority.

The registered geographical indication is then valid automatically in all members of OAPI, becoming an independent legal title in each of the countries, governed according to the law of that country which shall comply with the provisions of the Bangui Agreement. These two models of regional integration of geographical indication protection can contribute to the debate of an enhanced protection for geographical indication within ASEAN.

\section{Challenges for geographical indication protection in ASEAN countries}

\section{Top-down approach}

As for other IPRs, even if government officials become increasingly aware of the role of IPRs in economic development, the same awareness of geographical indications has not yet reached out to producers, rural communities, business, and civil society. ${ }^{123}$

\footnotetext{
${ }^{123}$ AFD/FAO report, Promotion of Rural Development through Development of Geographical Indications at Regional Level in Asia (GCP/RAS/281/FRA), 2013
} 
It is interesting to note that the legislations of all ASEAN countries allow producers, traders to register or claim on the geographical indications. Thailand ${ }^{124}$ and Indonesia ${ }^{125}$ even allow consumers to register for geographical indications. As in the case of Malaysia, persons entitled to apply for registration of a geographical indication include a person who is carrying on an activity as a producer in the geographical area; a competent authority; or a trade organization or association. ${ }^{126}$ However, due to the general absence of collective organization for the registered geographical indication, the lack of experience in the creation and management of such organizations (including financial and legal aspects) is also amplified by literacy and organizational weaknesses in rural areas as well as insufficient communication between producers, traders and other actors, geographical indication protection is mainly a top-down approach, with authorities, at local or national level identifying and registering geographical indication. In the case of Malaysia, due to the top-down approach, many Geographical Indications are registered without the knowledge of the producers and this leads to the redundancy as the geographical indications are not being managed and used despite the registration. This top-down approach needs to be reconsidered, with the creation of Producer/inter-professional organizations to be promoted or reinforced to guarantee the sustainability of geographical indication system development in ASEAN countries.

\section{Economic value from geographical indications}

Geographical indication protection itself builds up valuable reputations and goodwill for well-known local products. ${ }^{127}$ Research on economic aspects justifies benefits of geographical indications protection to maintain the reputation of products, help

\footnotetext{
${ }^{124}$ The Geographical Indications Protection Act of Thailand, Section 7 allows "group of consumers or organization of consumers of the goods using geographical indication" to register for geographical indications

125 The Regulation regarding Geographical Indications of Indonesia, Art. 5.3.c allows "a group of consumers of the goods" to register for geographical indications

${ }_{126}$ The Geographical Indications Protection Act of Malaysia, Section 11.

${ }^{127}$ Reviron Sophie (2009), Geographical Indications: Creation and distribution of economic value in developing countries, Swiss National Center of Competence in Research.
} 
producers obtain premium prices. ${ }^{128}$

Most geographical indications in ASEAN are linked to products related to agriculture, fisheries, crafts and artisanal works, which are also some of the sectors that provide livelihoods to large sections of the poor. It's too early to examine the socio-economic implications of geographical indication protection in ASEAN, because almost all of the ASEAN countries are in the very first steps of building geographical indication protection system. For Vietnam, except the case of Phu Quoc and Halong calamari in which there is an obvious change in the price of its products after the geographical indication registration, in other cases, there seems to be no remarkable change. ${ }^{129}$ Thailand is emerged to be the most successful in terms of trade when implementing geographical indication. ${ }^{130}$ There is a price change of products in Thailand before and after geographical indication registration. ${ }^{131}$

There are also indications that Sarawak Pepper, the first Malaysian geographical indication product and Kampot Pepper in Cambodia have managed to fetch higher prices as a result of the geographical indication registration. Sarawak Pepper can fetch around USD 6383 per metric ton and the Kampot Pepper has been selling in the market for around USD 26 per kilogram. ${ }^{132}$ However the price increase cannot be contributed to the geographical indications alone. Other factors contribute to the price increase such as the unique nature of the product, in this particular case white and black pepper which are prizes agriculture commodity in the world, the

\footnotetext{
${ }^{128}$ Shapiro, C (1983), "Premiums for high quality Product as a return to reputation", The Quarterly Journal of Economics, vol.97, pp 659-679"

${ }^{129}$ Le (2011), op.cit.,

130 Passerie S. (2014), FAO/AFD Project on the Promotion of Rural Development through Development of Geographical Indications at Regional Level in Asia, Regional Workshop on "Making Geographical Indications work for Rural Communities in lected Asian Countries: Identify Products and Drafting of Disciplinary for Geographical Indication Registration", Cambodia, December 2014

${ }^{131}$ Ibid, The price of Coffee Cherry Doi Chaang before/after registration is $4.50 \mathrm{baht} / \mathrm{kg}$ and $15 \mathrm{baht} / \mathrm{kg}$, it continues increasing to $28-32 \mathrm{baht} / \mathrm{kg}$. Price of pineapple Chiang Rai Phulae before $/$ after registration is $8 \mathrm{baht} / \mathrm{kg}$ and $23 \mathrm{baht} / \mathrm{kg}$ (price at farm) and $35 \mathrm{baht} / \mathrm{kg}-50 \mathrm{baht} / \mathrm{kg}$ (retail price), it reaches now $60 \mathrm{baht} / \mathrm{kg}$.

${ }^{132}$ Based on study of media reports of prices of Sarawak Pepper and Kampot Pepper by Sufian Jusoh. Files with Sufian Jusoh at sufianjusoh@gmail.com.
} 
management of the product and the geographical indications and the marketing effort that results in the higher demand for those products.

This allows other ASEAN countries to put their expectations on the benefits brought by geographical indication for unique and special products in these regions. The higher economic gain from the geographical indication products cannot be attributed to the registration of geographical indication alone, but due to other additional factors. Those factors include proper management of the geographical indication products through a standardized system resulting in the higher quality of the products and the existence of a proper system like production monitoring, standard operating procedures and compliance with the ISOs. There are many other geographical indication products which are not able to derive economic benefits due to the lack of proper management and lack of international and domestic marketing efforts on the part of the holders of those geographical indications. There is an incident of a government agency in Malaysia which controls a significant number of geographical indication products which refuse to manage the geographical indication and thus reducing any chance of increasing economic benefits of the products.

Explicit economic gains are important, but lack of use and poor management of geographical indications are two main issues that need to be tackled. ASEAN countries should take this up as a development issue, geographical indications being linked with the livelihoods of the people residing in the designated areas.

3. The costs of establishing and administering a geographical indication protection regime

A key consideration for ASEAN countries in approaching geographical indications, as would be the case with other forms of IPRs, relates to the costs of setting up the institutional framework for registering, administering and enforcing geographical 
indications in the country. Considering their human resources, financial and technical constraints, it is expected that in the short to medium-term, the costs for establishing and running the system will be reasonable when considering the economic value that might attach to their economies. Technical and financial assistance may obviate some of these constraints in the short-term.

\section{Technical assistance and capacity building}

There are significant technical and capacity needs which have to be addressed at different levels of developing and using a geographical indication as well as setting up a national protection system. During the past decade, IP Offices, and geographical indication divisions in Indonesia, Thailand, Vietnam, Cambodia have gained expertise in identifying geographical indication and support the drafting of geographical indication application following several cooperation and development projects. ${ }^{133}$ As a result, they were able to accompany the registration of 200 national geographical indications. This is not yet the case for Lao PDR, Brunei and Myanmar where a geographical indication division was just created and geographical indication officers were being trained.

For most ASEAN countries, it is still a challenge to afford the costs of all these technical and capacity components. An increased efficiency of geographical indication administrations (both publics and privates) is a key tool to support geographical indication system sustainability through improved protection, control, enforcement, commercialization and valorisation. It is, therefore, very important to favour nationally the creation of a cooperation mechanism between various agencies playing a role on national geographical indication development (such as IPOs, Department of Agriculture, Fishery, Tourism, Export promotion, Accreditation/control bodies, IP enforcement authorities, Consumer protection, etc.)

\footnotetext{
${ }^{133}$ Some examples for cooperation under ECAP Project, or under AFD or national program such as National Program supporting Intellectual Asset Development in Vietnam (Program 68)
} 
through the support of geographical indication National Committee' or geographical indication working group and MOU. Cooperation between public and private entities (NGOs, trade associations, etc.) is involved in rural development and trade promotion also needs to be further developed.

As we saw above, even if all ASEAN countries are members of WTO, there is a lack of harmonization of national domestic legal frameworks and there is no regional system, and no common IP Office. The experience of international protection can help imagine solutions to build up a facilitation system for ASEAN. 


\section{CHAPTER III: FACILITATING THE PROTECTION SYSTEM OF GEOGRAPHICAL INDICATIONS IN ASEAN}

In regional level, there is a lack of harmonization of national domestic legal frameworks and common system of geographical indication protection. While TRIPS Agreement and EU countries was the main models for implementing national law of geographical indication, this section gives some recommendations for ASEAN to consider in establishing long-term policy goals.

\section{Harmonization of national legal framework of ASEAN countries pushed by FTAs/RTAs}

In the region, each country retains responsibility for registering and protecting geographical indication in its territory. On many regards, improvements in IPRs administration efficiency can be achieved by harmonizing national systems regionally and internationally. In some areas, important steps have been taken in the region to set up multi-country arrangements (e.g.: ASPEC for Patents or ASEAN TMview for Trademark). TRIPS Agreement was the main model for implementing geographical indication laws in ASEAN countries, with some influences from bilateral cooperation and development projects from EU, France, and Switzerland.

More recently, another source of inspiration for domestic laws in ASEAN countries are above 156 RTAs/FTAs in which they are involved. The RTAs/FTAs with the participation of EU typically having provisions concerning the establishment of registration and recognition of selected European geographical indications, including geographical indications for wines and/or spirits, termed as TRIPS-plus 
provisions while the RTAs/FTAs with the participation $\mathrm{US}^{134}$ focusing on the replacement by trademark systems, termed as TRIPS-minus provisions. ${ }^{135}$ Participating in such agreements therefore, not only means that countries are agreeing to amend the national intellectual property law, but also means that they are likely to agree to standards that are far from their own economic and social needs. ${ }^{136}$ Some FTAs might have some impacts on the domestic legal framework but those FTAs are mainly meant for the protection of a list of geographical indications from signatory countries into the other Party, therefore, escaping from the long procedure of individual registration of each geographical indication in the other signatory Party.

Regarding the scope of protection, as Vietnam already has numerous geographical indications protected domestically, the FTA with the EU includes a list of $169 \mathrm{EU}$ geographical indications and 39 Vietnamese geographical indications. ${ }^{137}$ The level of protection to be granted to those particular geographical indications is ruled by the Agreement, with therefore the same protection for Vietnam geographical indications and EU geographical indications, according to a level of protection that is higher than what is provided in the Vietnam law but less than what is provided in the EU Regulation, with the prohibition of the use of geographical indication for goods not originating in the country, even where the true origin of the product is indicated or the geographical indication is used in translation or accompanied by expressions such as 'kind', 'type', 'style', 'imitation' or the like; for goods not produced according to the laws of the country of origin applying when the consumption is on the country of

\footnotetext{
${ }^{134}$ The US-Vietnam BTA were signed in 2001, the US-Singapore FTA implemented in 2007 and has been in force in January 2004. The US-Thailand FTA negotiations were launched in 2004 but suspended in 2006 following the dissolution of the Thai Parliament and the subsequent military-led coup.

${ }^{135}$ El-Said, M. (2005), The road from TRIPS-minus, to TRIPS, to TRIPS-plus. Implications of IPRs for the Arab world. Journal of World Intellectual Property, vol. 8, No. 1, pp. 53-65.

${ }^{136}$ Mercurio, B. (2006), TRIPS-plus provisions in FTAs: recent trends in Regional Trade Agreements and the WTO Legal System, Lorand Bartel and Federio Ortino, (eds. Oxford: Oxford University Press).

${ }^{137}$ The EU-Vienam FTA, Art. 6
} 
origin, in a way that indicates or suggests that the good in question originates in a geographical area other than the true place of origin in a manner which misleads the public or which constitutes an act of unfair competition Article 10bis of the Paris Convention (1967).

In the FTA with Singapore, the list has to be validated for enforcement, with the same scope of protection than what is provided in the EU-Vietnam FTA. Taking only the particular geographical indications listed in the Agreement into consideration, it is insufficient to conclude whether such provision will influence the national legal framework and enable any harmonization of national legislations in ASEAN, in a context where more over only 2 FTAs were finalized. It can, thus, be concluded that ASEAN was not a sufficiently solid partner for negotiations with the EU and bilateral relations were easier to conclude, in a context where ASEAN is not conferred the exclusivity for the negotiations of FTAs in the name of its members, as opposed to the EU.

On the other hand, some countries are also negotiating with the US, which focuses on a large extent of the elimination of domestic sui generis geographical indication protection system and their replacement by trademark system. ${ }^{138}$ The "TRIPSminus" geographical indication provisions could be found in US FTAs with Thailand $^{139}$, and Singapore ${ }^{140}$. However, the evolution of the geographical indication chapters in the FTAs with US has changed significantly over time. In the recent Trans-Pacific Strategic Economic Partnership Agreement (TPP), geographical indications protection has transformed from a part of trademark protection into an

\footnotetext{
138 Vivas-Eugui, D., and C. Spennemann (2006a). The treatment of geographical indications in recent regional and bilateral free trade agreements. Costa Rica: United Nations Conference on Trade and Development/International Centre for Trade and Sustainable Development Project on Intellectual Property and Sustainable Development

139 The Thailand-US FTA has launched negotiation since February 2006 and has not been concluded.

${ }^{140}$ The Singapore-US FTA, available at: https://ustr.gov/trade-agreements/free-trade-agreements/singapore-fta/finaltext
} 
independent system. ${ }^{141}$ The US and the alliance adopted, for the first time, a full section for geographical indication recognition and protection. ${ }^{142}$ There is, thus, less tension for ASEAN countries in geographical indication system implementation.

\section{ASEAN as a unique partner}

It is critical that none of the FTAs was directly negotiated by ASEAN but each individual country, which raises the issue of reinforcing ASEAN as a unique partner. At the international level, especially in the WTO forum, thanks to the power of numbers, ASEAN should have a significant impact on the direction of the multilateral trade agenda whereas such an outcome would not be feasible in a bilateral context. ${ }^{143}$ ASEAN should, thus, stress its position to support the multilateral trade rules of the TRIPS Agreement under the auspices of WTO. The country should actively work more closely together with other "geographical indication alliances" in order to make the geographical indication issue more public. The target should be not only to improve information for consumers of ASEAN geographical indications, which may act ultimately as "Ambassadors" of quality and know-how for the all chain of production, and the region of origin, in the global market but also to raise recognition from all parties about the importance of having domestic geographical indication better protected.

\section{Regional geographical indication website and Mandatory Database with all geographical indication registered in ASEAN for each country}

Currently, the visibility of geographical indication development in ASEAN is relatively low and the absence of a common regional platform to mutualize specific information and developments related to geographical indication is a weakness and a

\footnotetext{
${ }^{141}$ See TPP Agreement, Article 18

${ }^{142}$ Le Thi Thu Ha (2016), Conflict of geographical indications and trademark: from TRIPs Agreement to EU-VN FTA: Challenges for Vietnam, Journal of Laws, VNU

${ }^{143}$ Buckley, R., V.L. Lo, and L. Boulle (2008), Challenges to Multilateral Trade. The Impact of Bilateral, referential and Regional Agreements. Alphen aan den Rijn, The Netherlands: Kluwer Law International
} 
handicap to geographical indication visibility, exchanges and networking in the region. In that context, it is necessary to consider establishing a regional recognition of geographical indication through an online regional network.

ASEAN network is the common online geographical indications platform of the ASEAN Member States, which aims at making the information of all registered geographical indications in the ASEAN region widely available and easily accessible to all interested stakeholders. This database contains information on geographical indications having effects in the ASEAN countries, including comprehensive information fiches with the most relevant information for each one of them.

ASEAN have now a geographical indication Database ${ }^{144}$ developed by the Intellectual Property Offices of the ASEAN Member States with the support of the EU-ASEAN Project on the Protection of Intellectual Property Rights (ECAP III Phase II) administered by the EU Office for Harmonization in the Internal Market (OHIM). This website must be linked to the ASEAN portal as developed as a forum where all information and knowledge could circulate and where newcomers could find information according to their interest (both public and private). This website will be designed based on three main purposes:

- Mutualize information on geographical indication national system and development dedicated to targeted audiences;

- Promote geographical indication concept and visibility of geographical indication products and practical benefits of geographical indication;

- Encourage information exchange and discussion forum between geographical indication stakeholders (Public-Public, Public-Private and PrivatePrivate), business partners and other DPs.

${ }^{144}$ See the link at: http://www.asean-gidatabase.org/ 
ASEAN countries could, via their website on geographical indications, strengthen their socio-economic and cultural values, associated features such as the microenterprises they can spin off, and their attraction for tourism or investment. Anticipating more sophisticated cases of disputes over geographical indications, there is a need to determine and codify scientific attributes of their products on which legal verdicts can be based, instead of relying on subjective, connoisseur-determined statements on reputation, as is largely the case now.

\section{Legal effects to the Mandatory Database with all geographical indications registered in ASEAN}

Such register in the web-site could be used to facilitate the protection of geographical indications within ASEAN, following one of the model proposed under the TRIPS negotiation, or better the model proposed by the Geneva Act of the Lisbon Agreement, which could be enforced with ASEAN to become a party to the Geneva Act. 


\section{CONCLUSION}

The research raises questions concerning the interoperability of GIs protection at ASEAN level. The research focuses on one issue, whether or not there is any regional geographical indication protection at the level of ASEAN and whether there should be any.

Chapter 1 reviewed protection for geographical indications in ASEAN countries and a comparative analysis of ASEAN's countries domestic laws. This is evident from this insight that ten ASEAN countries have attempted to satisfy the definition of geographical indication stipulated in the TRIPS Agreement but each has a different way of wording and even a different requirement regarding the strength of the link with the origin, with the combination of natural and human factors being facultative or mandatory. While it may be assumed that ASEAN countries can benefit from GI protection, there is some evidence that GI protection would generate significant challenges for ASEAN countries, such as Top-down approach to GI protection, costs of establishing and administering a geographical indication protection regime, lack of harmonization of national domestic legal frameworks, no regional common IP Office..

Chapter II described the existing facilitation schemes for the protection of geographical indications at the international level and at the regional level in some areas in the world, namely the EU and the countries of West Africa. After TRIPS Agreement, there is no progress in facilitation system for the protection of geographical indications until the adoption of the Geneva Act of the Lisbon Agreement in May 2015. Lisbon system facilitates registration of already protected at national level appellation of origin/geographical indication in an International Register. The two models of regional integration of geographical indication 
protection (EU and OAPI) can contribute to the debate of an enhanced protection for geographical indication within ASEAN.

Chapter III focused on the possible ways to facilitate the registration and protection of geographical indications in the ASEAN region. From the experience of Europe, regional dynamic and harmonization could also faster national, regional but also international protection and recognition of geographical indication products. Protection of geographical indication makes a contribution to create a bridge that marries the old and the new: the national imperative of creating awareness about traditional products and knowledge, with preparation to engage internationally with the trade of goods and ideas in the twenty-first century. With single market of AEC, goods are travelling beyond borders within ASEAN countries, a regional geographical indication website and Mandatory Database is needed.

In conclusion, this research contributes an important understanding on geographical indication protection in ASEAN countries and the direction which ASEAN could facilitates the registration and notification of geographical indications. However, there is a lack of empirical research of economic benefits from geographical indication protection at ASEAN to the country. ASEAN countries as a unique partner should be a long-term policy goals. However, each member could work towards establishing a better national system to get a much better degree of information for policy-making and business decisions than countries in ASEAN have so far. From this insight, a strong political will is needed, with a strong political project for ASEAN, which was lacking during the last negotiations of the various important FTAs with the EU, the US or countries of the TPP. 


\section{BIBLIOGRAPHY}

1. AFD/FAO report, Promotion of Rural Development through Development of Geographical Indications at Regional Level in Asia (GCP/RAS/281/FRA), 2013

2. Buckley, R., V.L. Lo, and L. Boulle (2008), Challenges to Multilateral Trade. The Impact of Bilateral, referential and Regional Agreements. Alphen aan den Rijn, The Netherlands: Kluwer Law International

3. Chuthaporn Ngokkuen and Ulrike Grote (2012), Challenges and opportunities for protectiong geographical indications in Thailand, Asia-Pacific Development Journal, Vol. 19, No. 2, December 2012

4. Daniel J. Gervais, Traditional Knowledge: Are We Closer to the Answers? The Potential Role of Geographical Indications, ILSA Journal of International and Comparative Law 15, no. 2 (2009), p564.

5. El-Said, M. (2005), The road from TRIPS-minus, to TRIPS, to TRIPS-plus. Implications of IPRs for the Arab world. Journal of World Intellectual Property, vol. 8, No. 1, pp. 53-65.

6. Evans and Blakeney, The Protection of Geographical Indications after Doha: Quo Vadis?, p607.

7. Evans G.E. and Michael B. (2006), The protection of geographical indications after Doha: quo vadis?, Journal of International Economic Law, 1 of 40

8. Frank Fay, "EU system for geographical indications for agricultural products and foodstuffs", WIPO/GEO/SOF/09/4

9. Gopalakrishnan, N.S. et al (2007), Exploring the Relationship between geographical indications $s$ and TK: An Analysis of the Legal Tools for the Protection of geographical indications $s$ in Asia, ICTSD Programme on Intellectual Property Rights and Sustainable Development, International Centre for Trade and Sustainable Development, Geneva, Switzerland

10.Latha R. Nair \& Rajendra Kumar (2005), Geographical Indications: a search for identity, 2005, LexisNexis Butterworths, p. 95. 
11.Le Thi Thu Ha (2011), Protection of Geographical Indications in the context of Vietnam's international economic integration, Information and Communication Publishing House, August 2011

12.Le Thi Thu Ha, Conflict of geographical indications and trademark: from TRIPS Agreement to EU-VN FTA: Challenges for Vietnam, Journal of Laws, VNU

13.Marie-Vivien, Delphine, The Protection of Geographical Indications for Handicrafts: How to Apply the Concepts of Natural and Human Factors to All Products, WIPO Journal 4, no. 2 (2013), 191-203

14.Mercurio, B. (2006), TRIPS-plus provisions in FTAs: recent trends in Regional Trade Agreements and the WTO Legal System, Lorand Bartel and Federico Ortino, (eds. Oxford: Oxford University Press).

15.O'Connor Bernard (2003), The Laws of Geographical Indications, Cameron and May Publishing, London, page 52.

16.Passerie S. (2014), FAO/AFD Project on the Promotion of Rural Development through Development of Geographical Indications at Regional Level in Asia, Regional Workshop on "Making Geographical Indications work for Rural Communities in lected Asian Countries: Identify Products and Drafting of Disciplinary for Geographical Indication Registration", Cambodia, December 2014

17.Rangnekar Dwijen (2003), The social economic of Geographic Indications: the review of empirical of evidence from Europe, UNCTAD/ICTSD Capacity Building Project on IPR and Sustainable Development

18.Shapiro, C (1983), "Premiums for hight quality Product as a return to reputation", The Quarterly Journal of Economics, vol.97, pp 659-679"

19.Thitapha Wattannapruttipaisan (2009), Trademark and Geographical Indications: Policy issues and Options in Trade Negociations and Implementation, Asian Development Review, vol. 26, no. 1.

20.Vivas-Eugui, D., and C. Spennemann (2006a). The treatment of geographical indications in recent regional and bilateral free trade agreements. Costa Rica: United Nations Conference on Trade and Development/International Centre for Trade and Sustainable Development Project on Intellectual Property and Sustainable Development 
21.WIPO (2004), Geographical Indications: historical backgrounds, nature of rights, existing system for protection and obtaining protection in other countries, WIPO document $\mathrm{SCT} / 8 / 4$, available at: http://wipo.int/edocs/mdocs/sct/en/sct_8/sct_8_4.pdf 